\title{
Tracer Study of Teacher Education Graduates of the Eastern Visayas State University-Tanauan Campus, Philippines
}

\author{
Eduardo Edu C. Cornillez Jr., Sofio Rocky T. Caminoc, Belinda R. Basas, Benedicto T. Militante Jr., \\ and Ramelito R. Paler
}

\section{ABSTRACT}

The study's purpose was to examine the employment characteristics of teacher education graduates from the classes of 2013 to 2017. Specifically, to explore a graduate's perception of the extent of the relevance of their chosen program curriculum learning areas to employment, and the extent of the use of competencies and values they learned at university. A survey study design that is descriptive was utilized in the study with a random sample of 179 graduates identified as the primary study respondents. Based on the results, the majority of respondents were employed with permanent or regular employment status and worked locally within the region. Graduates' initial and current employment levels were professional, technical, or supervisory, and they were hired within 1 to 6 months of graduation. Salaries and benefits were the major factors in changing the first job careers of graduates. Moreover, graduates perceived the extent of the curriculum offered as relevant, and the general education and teaching practicum learning areas were found to be the most relevant areas that contribute the most to their employment. Communication, human relations, and self-assurance skills are the most useful workplace competencies and values. Students' university preparation has greatly aided their employment. Similar research may be undertaken in the future, which should include other school-related and employability variables not covered in the study.

Keywords: acquired competence, employment characteristics, learned values, teacher education graduates, the relevance of curriculum, tracer study.
Published Online: July 26, 2021

ISSN: $2736-4534$

DOI : $10.24018 /$ ejedu.2021.2.3.143

Eduardo Edu C. Cornillez Jr.*

Teacher Education Department, Eastern Visayas State University-Tanauan Campus, Tanauan, Leyte, Philippines.

(e-mail: eduardoedu.cornillez ${ }^{\circledR}$ evsu.edu.ph) Sofio Rocky T. Caminoc

Teacher Education Department, Eastern Visayas State University-Tanauan Campus, Tanauan, Leyte, Philippines.

(e-mail: sofiorocky.caminoc@evsu.edu.ph) Belinda R. Basas

Teacher Education Department, Eastern Visayas State University-Tanauan Campus, Tanauan, Leyte, Philippines.

(e-mail: belinda.basas ${ }^{\circledR}$ evsu.edu.ph)

Benedicto T. Militante Jr.

Teacher Education Department, Eastern Visayas State University-Tanauan Campus, Tanauan, Leyte, Philippines.

(e-mail: benedicto.militante ${ }^{\circledR}$ evsu.edu.ph) Ramelito R. Paler

Teacher Education Department, Eastern Visayas State University-Tanauan Campus, Tanauan, Leyte, Philippines.

(e-mail: ramelito.paler@evsu.edu.ph)

*Corresponding Author

\section{INTRODUCTION}

One of the primary functions of any Higher Educational Institution (HEI) is to produce excellent graduates who are prepared to enter the local and global labor market and contribute to the country's long-term growth. The major key drivers that HEIs are focused on are ensuring that graduates' skills and competence are aligned with global labor market demand for skilled employees [1]-[4]. Despite significant efforts by local and global development governments and groups to reduce unemployment, global graduate unemployment remains worse, with rates particularly high in emerging economies [5]-[9]. In the Philippines, according to the Philippine Statistics Authority's (PSA) 2019 report. In terms of educational attainment, the unemployment rate for junior high school graduates was $28.2 \%$, followed by college graduates at $20.9 \%$ and a college freshman at $8.2 \%$ [10].
From the local perspective in the eastern part of the Philippines, the labor regional director, Forter Puguon, came up with a projection that the region's unemployment rate in the Eastern Visayas region was expected to increase each year with thousands of fresh graduates seeking employment. According to [11] there are a huge number of HEI graduates in the region who are unemployed and do not earn income to contribute to the well-being of their families and the economic development of the region. Hence, unemployment and underemployment among graduates are indeed huge problems that the world is facing today.

The Commission of Higher Education (CHED), as part of the Philippine government's response, is constantly monitoring and reviewing each HEI's academic and nonacademic services to see if they match local and international standards. That is why one of the indicators that the CHED monitors is the graduate's employability. The Accrediting Agency of Chartered Colleges and Universities in the 
Philippines Inc., for example, requires documentation reports of graduate profiles as one of the documented requirements of higher education recognized bodies. Graduate employability, according to [12], is described as a person's capacity and desire to be and remain appealing in the global economy, or the relative possibilities of obtaining and maintaining certain types of work [12]. [14], "Employability of graduates, therefore, has become an issue that is not easy to be ignored in the global economy." For graduates to be employable, they need to possess the necessary competencies and skills that are flexible in the changing labor market. Understanding the employment characteristics and factors influencing graduate employment status is critical for HEIs [15]. The tracer study is one of the academy's monitoring measures for keeping track of its graduates' performance at work, how effective and efficient they are at completing the duties allocated to them, and the level of expectations they meet in comparison to their employer's expectations [16]. Similarly, through HEIs' continuous revision of curricula and evaluation through Graduated Tracer Study, the changing demands of existing and potential employers in society were effectively accommodated and assessed [17]. A study that provides significant input and information when evaluating a specific higher education institution in terms of their graduates' employability status and program outcome [18][22].

The Tanauan campus of Eastern Visayas State University is one of the universities in the Philippines' Eastern Visayas region that produces a large number of graduates each year. In response to the mandate of the CHED and alarming cases of unemployment and underemployment, this tracer study of the teacher education department was realized. The study will serve as a baseline for evaluating the university's response to producing exceptional and competent teachers, as well as for better understanding the employability variable that associates with the employability of teacher education graduates. Furthermore, to examine the graduates' employment service profiles and considering the significance of characteristics associated with the school in job placement. Investigating the benefits and drawbacks of the services provided and determining strategies that will help improve the graduate's employability.

\section{OBJECTIVES OF THE STUDY}

This paper examined the employment backgrounds of Eastern Visayas State University Tanauan campus teacher education graduates, as well as their perceptions of the relevance of their selected program curriculum, useful competencies, and values learned throughout their studies in the workplace. The study particularly answered the following research objectives.

1. Determine the graduates' demographic profile in terms of:

1.1 age;

$1.2 \mathrm{sex}$

1.3 civil status;

1.4 year of graduation;

1.5 degree program;

1.6 reasons for program selection; and

1.7 enrollment to another program.
2. Determine the characteristics of graduates' employment in terms of the following:

2.1 present employment classification;

2.2 employment place of work;

2.3 first job level position;

2.4 present job level position;

2.5 duration of acquiring the first job; and

2.6 gross monthly income.

3. Assess the extent of relevance of the program curriculum on employment of graduates in terms of:

3.1 general education;

3.2 professional education;

3.3 major courses;

3.4 industry immersion; and

3.5 teaching practicum.

4. Identify useful competencies and values acquired of the graduates in the university on their employment.

\section{THEORETICAL AND CONCEPTUAL FRAMEWORK OF THE STUDY}

The theory of Human Capital formed the basis for this paper [23], [24]. This theory explains the relationship between a graduate's educational background and the labor market. Education gives marketable skills and expertise essential to employee productivity. Therefore, the more educated a worker is, they will have a greater number of available and open employment opportunities, as well as a higher income in the labor market [25]. The human capital theory considers skills to be commodities, and it is founded on the assumption that a person will be able to invest in his or her studies since it will lead to more marketable qualities [26]. Because technological advancements require a bettereducated workforce for the productive system to operate properly, these skills will be recognized by demand in the labor market. [27], stated that the knowledge and skills acquired through education have a direct impact on worker's productivity. The present study assessed the graduate's employment characteristics and extent of contribution, relevance, and usefulness of the skills, training, and values that graduate acquired university employment. The theory explained the current study objectives of evaluating the graduates' competencies and skills obtained during their education for their employment experience. Figure 1 presents the graduate's demographic and employment variables used in the study.

The researchers determined the distribution of graduates according to the different profile variables. It includes the evaluation of the graduate's perceived relevance and usefulness of the program's curriculum and the competencies and values they learned in their employment. Graduate employment characteristics were also explored and investigated in terms of their initial and current employment. Descriptive statistical measurements were calculated to answer the study objectives. The study's findings provided important information to the university about the graduates' current status after graduation, as well as the quality of the academic curriculum and services provided by the university. 


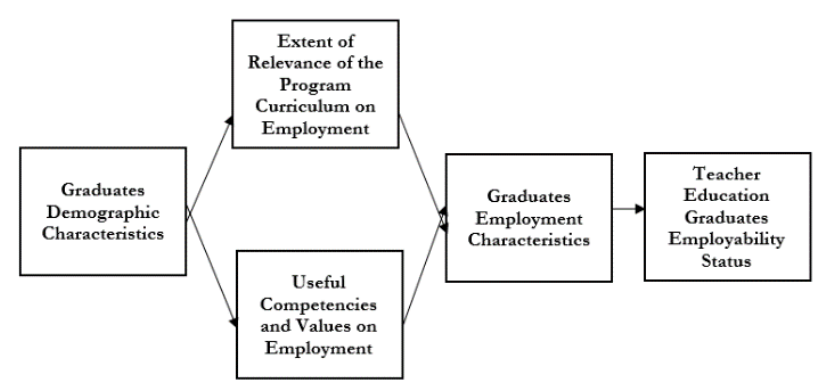

Fig. 1. Schematic Diagram showing the Conceptual Framework of the Study.

\section{Methodology}

\section{A. Research Design}

The researchers utilized a quantitative approach employing the descriptive survey research design [28], [29]. The study's approach was considered suitable since the objective was to track graduates' associated employment characteristics and examine the relevance of the graduates' acquired skills, competence, and values, as well as the university's curriculum program on their employment.

\section{B. Research Respondents}

A total of 249 teacher education graduates majors in Food Technology, Civil Technology, Electrical Technology, CITRA/Garments, Fashion and Design, and Physical Science of EVSU Tanauan campus were the target respondents of the study who graduated in the academic year of 2013 to 2017. For the study, a sample of 179 students was chosen using the sample size formula for a finite population with a $4 \%$ margin of error, a $95 \%$ level of confidence, and a proportion of $50 \%$ of the population [30]. In addition, to guarantee a good representation of graduates' respondents per school year, a stratified random sampling technique was applied in the sample's selection phase [31]. The proportionate study samples were chosen as follows: 15 graduates from the academic year 2013 were chosen, 18 from 2014, 27 from 2015, 45 from 2016, and 74 from 2017.

\section{Research Instrument}

The graduate tracer study questionnaire, which was adopted from the Commission of Higher Education Department, was used in this study (CHED). Some components of the questionnaire were revised to match the items with the study objectives. The questionnaire's items were all closed-ended and consisted of the following parts: Part I was concerned with the respondents' profile, which includes their age, sex, civil status, year of graduation, reasons for enrolling in the program, and enrollment in another degree program; Part II is concerned with the respondents' employability status, which includes their current employment status, current occupation, and place of work, duration of landing the first job, job level positions, and gross monthly earnings; Part III is concerned with the graduates' perceptions of the degree of relevance of the course program curriculum in terms of general education, professional education, major courses, industry immersion, and teaching practicum learning area competencies; and Part IV evaluated the graduates' university-learned useful competencies and values in their jobs.

\section{Data Gathering Procedure}

Written approvals were acquired from the head of the HEI where the study was conducted before the start of the study. A letter request was sent to the office of the registrar of the campus to ask for the list of the graduates' batches from 2013 to 2017. Personal distribution, telephone/cellphone connections, email addresses, and Facebook messaging with a letter informing the graduates of the study's purpose and requesting their involvement were all used to distribute the survey questionnaire. Voluntary participation of identified students' respondents was ensured. Also, for the ease of answering the online questionnaire, the researchers employed the Google form. The data collection process started in September 2019, until February August 2020.

\section{E. Treatment of Data}

After the data collection procedure, the data were recorded and tabulated and saved for analysis. Researchers calculated descriptive statistical measurements such as the frequency count, percentage, and ranking of frequency counts to explore the distribution of respondents according to profile, employment characteristics, learned competencies, and values while study. Besides, the weighted mean (WM) and standard deviation (SD) were computed to assess the extent of relevance of different program curriculum offered. All the analyses were done using Microsoft Excel.

\section{Results}

\section{A. Graduates Demographic Profile Characteristics}

Table I presents the university graduates distribution according to their age, sex, civil status, and year of graduation. The majority of the 179 samples (36.87\%) were between the ages of 32 and 37. It was followed by $34.64 \%$ of graduates ranging in age from 26 to 31 years old. Most of the graduates at $70.95 \%$ were females, and $81.01 \%$ were single.

TABLE I: DisTRIBUTION OF GRADUATES ACCORDING TO PROFILE

\begin{tabular}{ccc}
\multicolumn{2}{c}{ VARIABLES } & \\
\hline Age & Frequency & Percentage \\
32 to 37 years old & 62 & 34.64 \\
26 to 31 years old & 51 & 28.49 \\
20 to 25 years old & 66 & 36.87 \\
Sex & & \\
\multicolumn{1}{c}{ Female } & 127 & 70.95 \\
Male & 52 & 29.05 \\
Civil Status & 145 & \\
Single & 28 & 81.01 \\
Married & 4 & 15.64 \\
Single Parent & 1 & 2.23 \\
Common Law & 1 & 0.56 \\
Separated & & 0.56 \\
Year Graduated & 74 & 41.34 \\
2017 & 45 & 25.14 \\
2016 & 27 & 15.08 \\
2015 & 18 & 10.06 \\
2014 & 15 & 8.38 \\
2013 &
\end{tabular}

Note: $\mathrm{n}=179$.

Moreover, the study was mostly represented by the samples at $41.34 \%$ graduated in the graduation year of 2017 , while there was only $8.38 \%$ of graduates coming from the graduation year of 2013 . 
TABLE II: DISTRIBUTION OF GRADUATES ACCORDING TO DEGREE PROGRAM ATTENDED

\begin{tabular}{ccc}
\hline Degree Program & Frequency & Percentage \\
\hline BSIEd major in: & 58 & \\
Food Technology & 26 & 32.40 \\
CITRA & 10 & 14.53 \\
Electrical Technology & 5 & 5.59 \\
Automotive & 7 & 2.79 \\
Civil Technology & 73 & 3.91 \\
BSED Physical Science & & 40.78 \\
\hline
\end{tabular}

Note: $\mathrm{n}=179$.

Table II shows how graduates were distributed based on their degree program and specialization. The majority of graduates from the BSIEd program (32.40\%), are in Food Technology, followed by graduates majoring in CITRA $(14.53 \%)$. Only $2.79 \%$ were automotive specialists, with the remainder being electrical and civil technologists. On the other hand, $40.78 \%$ of teacher education graduates with a specialization in Physical Science took part in their studies.

TABLE III: DISTRIBUTION OF GRADUATES ACCORDING TO REASONS OF

\begin{tabular}{lcc}
\multicolumn{3}{c}{ PROGRAM SELECTION } \\
\hline \multicolumn{1}{c}{ Reasons for Taking the Course } & Percentage & Rank \\
\hline High Grades in Subject Area & 16.76 & 8 \\
Good Grades in High School & 32.96 & 2 \\
Influence of Parents & 35.20 & 1 \\
Peer Influence & 15.64 & 10 \\
Inspired by Role Model & 32.40 & 3 \\
Strong Passion for the Profession & 24.58 & 5.5 \\
Prospect for Immediate Employment & 17.32 & 7 \\
Status or Prestige of the Profession & 10.06 & 11 \\
Availability of the Course Offering & 24.58 & 5.5 \\
Prospect of Career Advancement & 16.20 & 9 \\
Affordability of the Family & 28.49 & 4 \\
The prospect of Attractive Compensation & 3.35 & 12 \\
Opportunity for Employment Abroad & 1.12 & 14 \\
No particular choice. & 2.23 & 13 \\
\hline
\end{tabular}

Note: Multiple responses

Table III reveals the distribution of graduates according to their reasons for enrolling in the program at the university. Parents' influence ranks number 1 as the primary reason for their program selection and is followed by having good grades in high school and being inspired by a role model in the third. The reasons for the availability of the course offerings and the strong passion for the profession were at the same rank, at 5.5.

TABLE IV: DISTRIBUTION OF GRADUATES ACCORDING TO ENROLLMENT

\begin{tabular}{lcc}
\multicolumn{3}{c}{ IN OTHER PROGRAM } \\
\hline Degree/Program & Frequency & Percentage \\
\hline BS Related Program & 9 & 6.87 \\
Master's Program & 36 & 20.11 \\
BS Unrelated Program & 3 & 1.68 \\
Non-Takers of other & 131 & 73.18 \\
degree programs & &
\end{tabular}

Note: $\mathrm{n}=179$.

Table IV shows that $73.18 \%$ of graduates did not enroll in another program after graduating from university. However, $20.11 \%$ of graduates were enrolled in graduate studies, a master's degree program and $6.87 \%$ were enrolled in a BSrelated related program.

\section{B. Graduates Employment Profile Characteristics}

Table V shows the employment status of graduates by current job level, first job level, place of employment, specific work position, and the number of unemployed graduates. According to graduates' current employment status, there were $87.71 \%$ of graduates were employed and only $12.29 \%$ were unemployed. Out of these employed graduates, the majority, at $40.78 \%$, were in a regular or permanent position. At $20.11 \%$ and $18.99 \%$ were in temporary and contractual positions, respectively. There were only $12.29 \%$ of unemployed graduates.

TABLE V: DISTRIBUTION OF GRADUATES BASED ON THEIR EMPLOYMENT

\begin{tabular}{|c|c|c|c|}
\hline \multicolumn{2}{|c|}{ Employment Status } & Frequency & Percentage \\
\hline \multirow{4}{*}{ Employed } & $\begin{array}{l}\text { Regular or } \\
\text { Permanent }\end{array}$ & 73 & 40.78 \\
\hline & Casual & 7 & 3.91 \\
\hline & Self-Employed & 7 & 3.91 \\
\hline & Temporary & 36 & 20.11 \\
\hline \multirow{3}{*}{ Not Employed } & Contractual & 34 & 18.99 \\
\hline & Unemployed & 22 & 12.29 \\
\hline & $\begin{array}{l}\text { Local within the } \\
\text { Region }\end{array}$ & 146 & 81.56 \\
\hline \multirow[t]{3}{*}{$\begin{array}{l}\text { Place of } \\
\text { Work }\end{array}$} & $\begin{array}{l}\text { Local outside the } \\
\text { Region }\end{array}$ & 10 & 5.59 \\
\hline & Abroad & 1 & 0.56 \\
\hline & $\begin{array}{l}\text { Rank or Clerical } \\
\text { Professionals, }\end{array}$ & 66 & 36.87 \\
\hline \multirow{5}{*}{$\begin{array}{l}\text { First Job } \\
\text { Level } \\
\text { Position }\end{array}$} & Technical or & 70 & 39.11 \\
\hline & Supervisory & & \\
\hline & $\begin{array}{l}\text { Managerial or } \\
\text { Executive }\end{array}$ & 4 & 2.23 \\
\hline & Self-Employed & 17 & 9.50 \\
\hline & $\begin{array}{l}\text { Rank or Clerical } \\
\text { Professionals, }\end{array}$ & 47 & 26.26 \\
\hline \multirow{4}{*}{$\begin{array}{l}\text { Present Job } \\
\text { Level } \\
\text { Position }\end{array}$} & Technical or & 96 & 53.63 \\
\hline & Supervisory & & \\
\hline & $\begin{array}{l}\text { Managerial or } \\
\text { Executive }\end{array}$ & 4 & 2.23 \\
\hline & Self-Employed & 10 & 5.59 \\
\hline
\end{tabular}

Note: $n=179$.

Moreover, most of the graduates at $81.56 \%$ are working locally or within the region. A large number of graduates at $39.11 \%$ are in the job level position as professional, technical, and supervisory, and $36.87 \%$ are in the clerical or rank position. In the present job level position of the graduates, there was an increasing percentage of graduates at $14.52 \%$ who are now working as professional, technical, and supervisory in comparison in the graduate's fist job level position. A significant proportion of teacher education graduates were professionally employed, based on the findings of the study of [32].

\begin{tabular}{lcc}
\multicolumn{3}{c}{ TABLE VI: DistRIBUTION OF GRADUATES BY FIRST EMPLOYMENT } \\
STATUS
\end{tabular}

Note: $\mathrm{n}=179$.

It can be gleaned in Table VI the transition time from graduation to the first employment of the graduates, and the reasons why they left their first job and sought another one. The most of graduates, $33.52 \%$, find their first employment within one to six months of graduation. Sixty points seventyone percent $(6.71 \%)$ of graduates obtain their first job within 
a month of graduation, while just $4.47 \%$ had to wait for 3 to 4 years after graduation to get their first employment. On the one hand, after graduating, the highest percentage of graduates, $48.60 \%$, left their first job and sought another for salary and benefits reasons. This is followed by career challenges for nearly $24 \%$ of the reasons. And other reasons for leaving the first job were related to special skills and proximity to residence. Similar results were found in the tracer studies conducted by [32], and [33] that the major factors for shifting jobs are career challenges, salary, and benefits.

TABLE VII: DISTRIBUTION OF GRADUATES BY GROSS MONTHLY INCOME

\begin{tabular}{llcc}
\hline \multirow{2}{*}{ Gross Monthly Income } & $\begin{array}{c}\text { Frequenc } \\
\text { y }\end{array}$ & Percentage \\
\hline \multirow{5}{*}{ First Job } & 25,000 and Above & - & - \\
& 20,000 to less than 25,000 & 41 & 22.91 \\
& 15,000 to less than 20,000 & 12 & 6.70 \\
& 5,000 to less than 15,000 & 40 & 22.35 \\
& 5,000 to less than 10,000 & 49 & 27.37 \\
& Below 5,000 & 15 & 8.38 \\
25,000 and Above & 1 & 0.56 \\
Job & 20,000 to less than 25,000 & 64 & 35.75 \\
& 15,000 to less than 20,000 & 13 & 7.26 \\
& 10,000 to less than 15,000 & 18 & 10.06 \\
& 5,000 to less than 10,000 & 44 & 24.58 \\
Nete: $\mathrm{n}=179$. & 17 & 9.50 \\
\hline
\end{tabular}

Table VII demonstrates the gross monthly income of the graduates based on their initial job and current job. Most graduates have a monthly income of 5,000 to less than 10,000 according to their first job. There are $22.91 \%$ of graduates with incomes ranging from 20,000 to less than 25,000. Most graduates $(35.75 \%)$ have a monthly income of 20,000 to less than 25,000 in their current job. There was 1 or $0.56 \%$ whose income was 25,000 and above. The results show that the salary and benefits reasons in Table VI for why graduates leave their first job are very visible in the number of graduates who have a higher income in their current job than in their first job. Similar findings were yielded in the tracer study of [34] that most of the teacher education graduates earned a monthly salary of 20,000 to 25,000 pesos.

\begin{tabular}{lccc}
\multicolumn{4}{c}{ TABLE VIII: EXTENT OF RELEVANCE OF THE PROGRAM CURRICULUM } \\
\hline \multicolumn{1}{c}{ Learning Areas } & WM & SD & Interpretation \\
\hline General Education & 4.12 & 0.46 & Relevant \\
Professional Education & 4.07 & 0.52 & Relevant \\
Major Courses & 4.08 & 0.67 & Relevant \\
Industry Immersion & 3.91 & 0.85 & Relevant \\
Practice Teaching & 4.10 & 0.40 & Relevant \\
\multicolumn{1}{c}{ Overall } & 4.06 & 0.58 & Relevant
\end{tabular}

Note: 1.00-1.80 - Not relevant; 1.81-2.60 - Slightly relevant; 2.61-3.40 Moderately relevant; 3.41-4.20 - Relevant; 4.21-5.00 - Highly relevant.

As shown in Table VIII, the graduates perceived the extent of relevance of their chosen program curriculum to be relevant overall $(W M=4.06, S D=0.58)$. All the learning areas were found by the graduates as relevant factors in their employment. It can be observed that the general education $(W M=4.12, S D=0.46)$ and practice teaching $(W M=4.10$, $S D=0.40$ ) learning areas obtained the least variation in responses among the learning areas identified, which implies that the graduates perceived these factors consistently and homogeneously to be relevant to their employment. On the other hand, graduates in the industry immersion learning area obtained the lowest mean $(\mathrm{WM}=3.91, \mathrm{SD}=0.85)$, interpreted as relevant. According to [35] and [45], the employability of graduates can be increased when the design of the curriculum is centered more on the apprenticeship and industry immersion of students, which provides them with job training that is useful for employment. Also, [46] and [47] emphasizes the significance of practice teaching in preparing the graduates in becoming a teacher and its impact on the performance of certain educational institutions.

TABLE IX: LEARNED USEFUL COMPETENCIES ON EMPLOYMENT

\begin{tabular}{lccc}
\hline \multicolumn{1}{c}{ Learned Competencies } & Frequency & Percentage & Rank \\
\hline Communication Skills & 126 & 70.39 & 1 \\
Human Relation Skills & 100 & 55.87 & 2 \\
Entrepreneurial Skills & 42 & 23.46 & 6 \\
Information Technology Skills & 68 & 32.40 & 4.5 \\
Problem-Solving Skills & 68 & 32.40 & 4.5 \\
Critical Thinking Skills & 70 & 39.11 & 3 \\
\hline Note: Multiple responses & & &
\end{tabular}

Table IX shows that among the competencies learned by the graduates in the university, the communication skills at $70.39 \%$ ranks as number 1 which indicates that they perceived this skill to be very useful competence on employment. This was followed by the skills related to human relations at $55.87 \%$ and critical thinking skills at $39.11 \%$. Further, the skills linked to information technology and communication (ICT) and problem-solving were discovered to be in the same ranking as very useful learned competencies on the job. Entrepreneurial related skills were the least chosen skills of the graduates that were useful in their employment. The results were supported by the studies of [36]-[38] that possessing good English and communication competencies were high demand and essential skills for graduates employment, while graduates with poor English and computer skills would make unemployed [39]. Also, similar findings were revealed in the tracer studies of [34] and [40] that the most useful competencies of their graduates learned were human relations and communications. Communication and information technology skills, on the other hand, were the top skills regarded useful in the work, according to [41].

TABLE X: LEARNED USEFUL VALUES ON EMPLOYMENT

\begin{tabular}{lccc}
\hline \multicolumn{1}{c}{ Values learned } & Frequency & Percentage & Rank \\
\hline Competence & 103 & 57.54 & 2 \\
Compassion & 74 & 41.34 & 6.5 \\
Honestly & 94 & 52.51 & 3 \\
Punctuality & 68 & 37.99 & 8 \\
Leadership & 86 & 48.04 & 4 \\
Confidence & 105 & 58.66 & 1 \\
Faith & 65 & 36.31 & 9.5 \\
Diligence & 65 & 36.31 & 9.5 \\
Zeal for Service & 64 & 35.75 & 11 \\
Sociability & 74 & 41.34 & 6.5 \\
Commitment & 54 & 30.17 & 14 \\
Hope & 59 & 32.96 & 13 \\
Work & 78 & 43.58 & 5 \\
Creativity & 61 & 34.08 & 12 \\
\hline Not & & &
\end{tabular}

Note: Multiple responses.

Table $\mathrm{X}$ denotes that the confidence value at $58.66 \%$ was the most useful value for employment that the graduates perceived that they learned at university. This was followed by $57.54 \%$ for competence, $52.51 \%$ for honesty, and $48.04 \%$ for leadership. Whereas the values of commitment and hope were ranked the least among the values identified. Also, the values of having faith and being diligent in employment were 
perceived by the graduates in the same manner as being useful, as these values were ranked the same at 9.5.

\section{CONCLUSIONS AND RECOMMENDATIONS}

According to the study's findings, the employability status of teacher education graduates was extremely favorable. The graduates chose the education-related program as their university degree as influenced by their parents and good academic performance in high school. Most of the graduates of the batch of 2013 to 2017 were employed with regular or permanent job status. Graduates work as professionals and earn salaries ranging from 20,000 to less than 25,000 pesos. The majority of them took 1 to 6 months to get their first job, and the primary reason for leaving their first job was salary and benefit considerations. All of the program's learning areas were deemed relevant to graduates' employment, with the general education and practice teaching learning areas getting the highest mean score. Communication and human relations skills were found by the graduates to be the most useful competencies in the workplace. Confidence and competence were the most useful values for employment, according to the graduate's evaluation. Entrepreneurial skills and commitment to value, on the other hand, were perceived as the least useful competencies and values for employment by teachers' education graduates. The study results only give emphasis on the importance of a student's feedback in measuring the quality of the academic and non-academic performance of a certain higher educational institution [42][44].

The researchers suggest that the university's teacher education department should continue strengthening the program curriculum areas of the BSEd and BSIEd programs to increase the perceived relevance of the graduates to employment from relevant to highly relevant. Enhancing the opportunity for students to receive incredibly beneficial onthe-job training to provide them with meaningful experiences and the skills required in the workplace, particularly in the present pandemic situation. The university should continue to develop, monitor, and strengthen students' communication and human relations skills, as these are regarded as the most useful skills acquired by graduates for employment. Students' confidence and competence must be developed continuously. A yearly update of a graduate's employability status should be conducted for monitoring and validation of the study results. Other employment variables that were not covered in the study should be included, such as professional training and seminars attended by graduates, reasons why graduates are not employed, the methods graduates use to find a job, graduates' perceptions of the adequacy of university facilities, and professional examinations such as the Licensure Examination.

\section{ACKNOWLEDGMENT}

The authors would like to express their gratitude to the Eastern Visayas State University Office of the Research, Development, and Extension (EVSU-ORDEx) in the Philippines for granting them to conduct the study. Also, appreciation to all of the teacher education graduates from 2013 to 2017 who took part in the study.

\section{REFERENCES}

[1] P. G. Altbach, L. Reisberg, and L. E. Rumbley, "Trends in global higher education: Tracking an academic revolution. A Report Prepared for the UNESCO 2009 World Conference on Higher Education, 2009 http://atepie.cep.edu.rs/public/Altbach,_Reisberg,_RumbleyTracking _an_Academic_Revolution,_UNESCO_2009.pdf.

[2] N. Broussard and T. G. Tekleselassie, "Youth unemployment: Ethiopia country study," International Growth Centre. Working Paper, vol. 12, no. 0592 , pp. 1-37, 2012. http://prime-ethiopia.org/wpcontent/uploads/2015/03/Youth\%20UnemploymentEthiopia\%20Country\%20Study.pdf.

[3] R. D. Martin, "The importance of communication competency for employability," Procedia - Social and Behavioral Sciences, vol. 139, pp. 387-394, 2014. https://doi.org/10.1016/j.sbspro.2014.08.024.

[4] T. T. Rojas and R. C. Rojas, "College of Education Graduate Tracer Study (GTS): Boon or Bane?” European Scientific Journal, vol. 12, $\begin{array}{llll}\text { no. } & 16, & \text { pp. } & 63-78,\end{array}$ http://dx.doi.org/10.19044/esj.2016.v12n16p63.

[5] C. E. Okojie, "Employment creation for youth in Africa: the gender dimension," Jobs for Youth: National Strategies for Employment Promotion, pp. 15-16, 2003.

[6] A. Galal, "The road not traveled: education reform in the Middle East and North Africa," World Bank Publications, 2008.

[7] N. Ismail, "Graduates' characteristics and unemployment: A study among Malaysian graduates," International Journal of Business and Social Science, vol. 2, no. 16, 2011.

[8] G. Simpsons, "Youth unemployment: A danger for Africa's failure," Africa Rising Maryland, USA, pp. 34, 2011.

[9] N. E. Nikusekela and E. N. Pallangyo, "Analysis of supply side factors influencing employability of fresh higher learning graduates in Tanzania," Global Journal of Human-Social Science Economics, vol. 16, no. 1, 2016.

[10] Philippines Statistics Authority. (2019). Employment rate in January 2019 is estimated at 94.8 percent. https://psa.gov.ph/content/employmentrate-january-2019-estimated948-percent.

[11] J. A. Austero, P. T. Armenia, and M. N. V. Seriño, "Employment outcomes of graduates in selected higher educational institutions in Eastern Visayas, Philippines," Annals of Tropical Research, vol. 34, no. 1, pp.147-162. https://cdn.annalsoftropicalresearch.com/wpcontent/uploads/pdf_files /Volume34No.1/9.pdf.

[12] M. Coetzee and D. Schreuder, "The relation between career anchors, emotional intelligence and employability satisfaction among workers in the service industry," Southern African Business Review, vol. 15, no. 3, pp. 76-97, 2011 https://journals.co.za/doi/pdf/10.10520/EJC92935.

[13] P. Brown, A. Hesketh, and S. Williams, "The mismanagement of talent: Employability and jobs in the knowledge economy. Oxford University Press on Demand, 2004. https://doi.org/10.1093/acprof:oso/9780199269532.001.0001.

[14] R. K. Misra and K. Khurana, "Employability skills among information technology professionals: A literature review," Procedia Computer

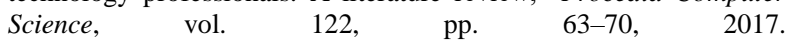
https://doi.org/10.1016/j.procs.2017.11.342.

[15] D. J. Finch, L. K. Hamilton, R. Baldwin and M. Zehner, "An exploratory study of factors affecting undergraduate employability,' Education+ Training, vol. 55, no. 7, pp. 681-704, 2013. https://doi.org/10.1108/ET-07-2012-0077.

[16] L. O Aina and K. Moahi, "Tracer study of the Botswana library school graduates," Education for information, vol. 17, no. 3, pp. 215-244, 1999.

[17] M. J. F. Cañizares, “Tracing University of San Carlos' science and mathematics education graduates: How well are we in developing teacher professionals? International Journal of Research Studies in Education, vol. 4, no. 2, pp. 69-86, 2015. https://doi.org/10.5861/ijrse.2015.985.

[18] M. B. De Ocampo, A. J. Bagano, and A. Tan, "Culture of entrepreneurship versus employment," 2012 Fifth Taiwan-Philippines Academic Conference Digital Humanities and Cultural Studies. Aletheia University, New Taipei City, Taiwan, 2012.

[19] U. Teichler, "Lessons to be learned from Graduates: Interpretation of the Results of Graduate Surveys," Kassel: INCHER-Kassel UNITRACE, 2011.

[20] H. Schomburg and U. Teichler, "Employability and mobility of bachelor graduates in Europe. New York: Springer, 2011. https://www.uni-kassel.de/einrichtungen/fileadmin/datas/ 
einrichtungen/incher/T_15

EMBAC_Schomburg_Teichler_2011.pdf.

[21] D. Herrmann, B. Dilger and M. Junghanns, "Specialized questionnaires in graduate tracer studies; Demand, development and back channeling results," Koln: University of Cologne, 2010.

[22] H. Schomburg, "Handbook for Tracer Studies," Center for Research on Higher Education and Work, University of Kassel, Germany, 2003.

[23] T. W. Schultz, "Investment in human capital," The American Economic Review, vol. 5, no. 1, pp. 1-17, 1961.

[24] G. S. Becker, "Human capital: A theoretical and empirical analysis, with special reference to education. Chicago: University of Chicago Press, 1964

[25] Y. Cai, "Graduate employability: A conceptual framework for understanding employers' perceptions," Higher Education, vol. 65, no. 4, pp. 457-469, 2013.

[26] E. Weber, "Shifting to the right: the evolution of equity in the South African government's developmental and education policies, 19901999," Comparative Education Review, vol. 46, no. 3, pp. 261-290, 2002. https://doi.org/10.1086/341158.

[27] G. S. Becker, "Human capital. The concise encyclopedia of economics," 2 , http://ndl.ethernet.edu.et/bitstream/123456789/28255/1 /33..pdf.

[28] H. Nassaji, "Qualitative and descriptive research: Data type versus data analysis," Language Teaching Research, vol. 19, no. 2, pp. 129132, 2015. https://doi.org/10.1177/1362168815572747.

[29] K. A. Cox, "Quantitative research designs” In G. J. Burkholder, K. A. Cox, \& L. M. Crawford (Eds.), “The Scholar-Practitioner's Guide to Research Design", Baltimore, MD: Laureate Publishing, 2016.

[30] R. Valliant, J. A. Dever, and F. Kreuter, "Practools: Computations for design of finite population samples," $R J$, vol. 7, no. 2, pp. 163-176, 2015 .

[31] S. Rahi, "Research design and methods: A systematic review of research paradigms, sampling issues and instruments development," International Journal of Economics \& Management Sciences, vol. 6, no. 2, pp. 1-5, 2017. 10.4172/2162-6359.1000403.

[32] A. B. Aquino, E. J. Punongbayan, L. P. Macalaguim, S. M. Bauyon, R. A. Rodriquez Jr., and G. R. Quizon, "Teacher education graduate tracer study from 2010 to 2014 in one state university in Batangas, Philippines," Asia Pacific Journal of Multidisciplinary Research, vol. 3, no. 5, pp. 45-50, 2015. https://www.apjmr.com/wpcontent/uploads/2016/01/APJMR-2015-3.5.2.06.pdf.

[33] P. Ghosh, R. Satyawadi, J. P. Joshi, and M. Shadman, "Who stays with you? Factors predicting employees' intention to stay," International journal of organizational analysis, vol. 21, no. 3, pp. 288-312, 2013. https://doi.or/10.1108/IJOA-Sep-2011-0511.

[34] M. L. Pacleb-Ulanday, "Tracer study and employability skills acquisition of teacher education graduates," Psychology and Education Journal, vol. 58, no. 4, pp. 1678-1683, 2021.

[35] D. Shukla, "Employability Skill among Professionals-Chagrin of HR Executives in Indian Labor Market: A Study on Engineering Graduates of Bhopal City," VSRD International Journal of Business and Management Research, vol. 2, 2012.

[36] T. L. Clokie and \& E. Fourie, "Graduate employability and communication competence: Are undergraduates taught relevant skills? Business and Professional Communication Quarterly, vol. 79, no. 4, pp. 442-463, 2016.

[37] A. V. Bharathi, "Communication skills-core of employability skills: Issues \& concerns. Higher Learning Research and Communication," vol. 6, no. 4, 2016 https://files.eric.ed.gov/fulltext/EJ1132742.pdf.

[38] R. Paulrajan, "Employability skills in Chennai Retail Market, India," ACTA UNIVERSITATIS DANUBIUS, vol. 7, no. 5, 2011.

[39] R. Nagarajan, "Poor English, computer skills make graduates unemployable," Times of India, 2013.

[40] M. I. C. Celis, B. Festijo, and A. Cueto, "Graduate's employability: A tracer study for Bachelor of Science in Hotel and Restaurant Management," Asian Academic Research Journal of Multidisciplinary, vol. 1, no. 11, pp. 225-238, 2013.

[41] L. Macatangay, "Tracer study of BSCS graduates of Lyceum of the Philippines University from 2004-2009," Academic Research International, vol. 4, no. 5, pp. 361, 2013.

[42] E. E. C. Cornillez Jr, "Instructional quality and academic satisfaction of university students," European Journal of Education Studies, vol. 6, no. 4, pp. 13-31, 2019. https://doi.org. 10.5281/zenodo.3269406.

[43] H. C. Encabo, "Canonical correlation analysis of student perception on instructional quality and satisfaction," JPAIR Multidisciplinary Journal, $\quad$ vol. $\quad 6, \quad$ pp. $1-16, \quad 2011$. http://www.academia.edu/download/7148997/Multidiciplinary\%20jo urnal.pdf.

[44] F. T. Abocejo and R. N. Padua, "An econometric model for determining sustainability of basic education development," $C N U$
Journal of Higher Education., vol. 4, no. 1, pp. 40-53, 2010. http://www.jhe.cnu.edu.ph/index.php/cnujhe/ article/view/39.

[45] R. Chithra, "Employability Skills-A Study on the perception of the engineering students and their prospective employers," Global Journal of Management and Business Studies, vol. 3. No. 5. pp. 525-534, 2013.

[46] M. B. Ulla, "Pre-service teacher training programs in the Philippines: The student-teachers practicum teaching experience," EFL journal, vol. 1, no. 3, pp. 235-250, 2016.

[47] R. B. Mahinay, "Contextual performance of teacher education institutions (TEIs) in the Philippines," 2013. https://www.researchgate.net/publication/236622259_Contextual_Per formance_of_Teacher_Education_Institutions_TEIs_in_the_Philippin es.

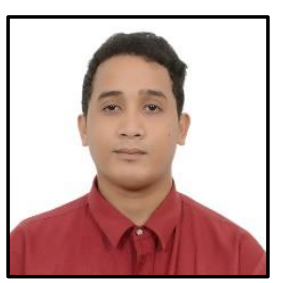

Eduardo Edu C. Cornillez Jr. currently resides in Tacloban City, Philippines. He has been a faculty since 2017 . He received the Magna Cum Laude honor for his bachelor's degree in statistics from the EVSU Tacloban Campus. $\mathrm{He}$ is currently pursuing a Master's degree in Mathematics Education at Leyte Normal University (LNU) in Tacloban City, Philippines. $\mathrm{He}$ is a faculty member of Eastern Visayas State University - Tanauan Campus in Tanauan, Leyte, Philippines, where he teaches Mathematics and Statistics to students in various degree programs while also serving as the department's faculty research coordinator. He is also a Managing Editor for the university's peer-reviewed journal, the TARAN-AWAN Journal of Educational Research and Technology Management. In 2020, he volunteered as a data interpreter for the Department of Science and Technology - Philippine Council for Health Research and Development (DOST-PCHRD) project titled "Feasibility Analysis of Syndromic Surveillance Using Spatio-Temporal Epidemiological Modeler" (FASSSTER) for LGU Epidemiology Surveillance Units for Leyte Province, Philippines.

Mr. Cornillez won best presenter and best paper for mathematics category during the 2nd International Science, Technology, Engineering, AgriFisheries, and Mathematics (STEAM) research congress held last August 2018 at the Summit Hotel in Tacloban City, Philippines. He was an EVSU -TC campus research performance awardee in 2019 and 2020. His research and publication interests includes in the fields of educational management, mathematics education, statistics, technology in education, social sciences, teaching and learning, and data mining.

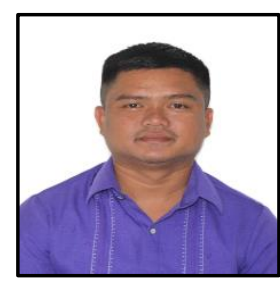

Sofio Rocky T. Caminoc Currently resides at Barangay Calubian Dulag, Leyte in the Philippines. He studied his elementary education at San Jose Central School, San Jose Dulag, Leyte, while his secondary education at Dulag National High School, Dulag, Leyte. He earned units at the University of the Philippines in the Visayas Tacloban College with the program Bachelor of Arts in Social Science Major in Political Science. However, with his desire in becoming an educator he enrolled Bachelor of Science in Industrial Education Major in Civil Technology at Eastern Visayas State University Tanauan Campus, Tanauan Leyte, Philippines and graduated in the Year 2016 as an Academic Excellence Awardee. He is presently a Master's candidate in Industrial Technology Education at Palompon Institute of Technology in Palompon, Leyte, Philippines.

$\mathrm{He}$ is currently a member of the Teacher Education Department of Eastern Visayas State University, Tanauan Campus, Tanauan Leyte, Philippines, where he also serves as the Coordinator of the Campus's Alumni Relations and Affairs Office. He is also the Program Coordinator for the Bachelor of Technology and Livelihood Education (BTLEd) Major in Home Economics (HE) and Industrial Arts (IA). He is one of the authors of a recently published international study titled "Effects of Polythelene Ground Plastic Waste Aggregate on Concrete Mixing Proportion" in the journal Engineering \& Technology Review). He is also looking forward to work on research pertaining to his field of interest, Civil Technology, Industrial Technology, research on Education, and the likes.

Mr. Caminoc is a member of Philippine Association for Teachers and Education (PAFTE) Region VIII, which serves as an avenue for him to continually develop and adopt to various teaching strategies and approaches in the new normal. 


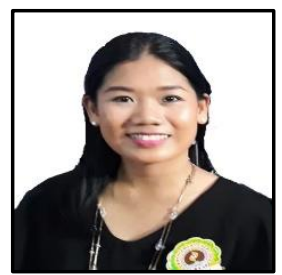

Belinda R. Basas resides in Tanauan, Leyte, Philippines. She is a Master of Arts in Teaching Science candidate at Leyte Normal University in the Philippines. She is a science faculty member in the teacher education department as well as the department's extension services coordinator and campus environment protection and maintenance coodinatore. She is the proponent of the university's Recycle to Live Sustainable Livelihood Program on Solid Waste Management Practices in the community. She teaches courses in the areas of sciences and in professional education.

Ms. Basas' research interests include applied science, teaching and learning in Science, educational management, and community development. One of her publication is Science Teachers' Teaching Competence and Student Satisfaction in the TARAN-AWAN Journal of Educational Research and Technology Management.

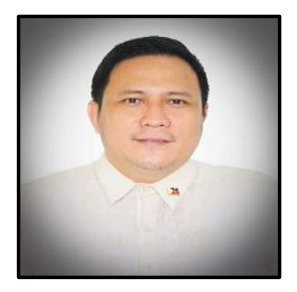

Benedicto T. Militante Jr. lives in Libertad Palo, Leyte, Philippines. In 2015, he received his Juris Doctor from St. SPaul's School of Business and Law College of Law in Palo, Leyte, Philippines. In 2010, he earned a Doctor of Philosophy with a major in educational program management from Eastern Visayas State University's Main Campus in Tacloban City, Philippines.

$\mathrm{He}$ is an Associate Professor V at Eastern Visayas State University-Tanauan Campus (EVSU-TC) in Tanauan, Leyte, Philippines. Beginning November 2019, he has served as the Director of EVSU-TC, and from 2009 until the present, he has acted as the Head of EVSU-Quality TC's Assurance Center. He is an Associate Editor for the TARAN-AWAN Journal of Educational Research and Technology Management, the university's peer-reviewed journal. Some of his research publications include Esl Learners and Do You Need Mall (Mobile-Assisted Language Learning) in the Solid State Technology journal (2020); Teaching Non-Major Subjects: Lived Experiences of DepEd SHS Teachers in the Solid State Technology journal (2020); and Physical Resources of Civil Engineering Program among Government Universities in the Eastern Visayas Region, Philippines in the Aloha International Journal of Management (2019). His research interests are in the fields of educational and public policy, educational management, industrial education, civil technology, teaching pedagogies, and technology in education.

Dr. Militante is a Senior Accreditor/Evaluator of the Accrediting Agency of Chartered Colleges and Universities of the Philippines, an Assessor of the Regional Quality Assessment Team of the Commission on Higher Education Region VIII (CHED-RO8), and a Lifetime member of the Confederation of Faculty Associations of the Philippines, to name a few of his reputable affiliations with associations and organizations.

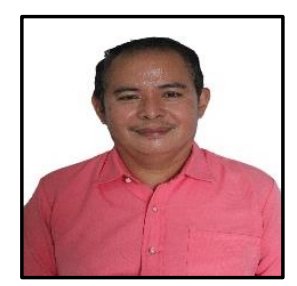

Ramelito R. Paler is an Associate Professor III at Eastern Visayas State University - Tanauan Campus (EVSU-TC) in the Philippines. He is currently the Head of the EVSU-TC Teacher Education Department. He was the university's Head of Research Office before becoming the head of the teacher education department. He received his doctorate in technology management from Cebu Technological University in the Philippines. He teaches professional education, industrial education, and arts and humanities courses.

Dr. Paler is a member of the Editorial Board of the TARAN-AWAN Journal of Educational Research and Technology Management, which is a multidisciplinary, peer-reviewed journal operated by the EVSU-TC. Some of his publications include the Effects of Polyethylene Ground Plastic Waste Aggregate for Concrete Mixing Proportion in the journal Engineering \& Technology Review (2021); the Effectiveness of Assimilating Technology in Drafting in the International Journal of Scientific \& Technology Research (2019); and The Physical Health Condition and Income of Pot Makers in the journal Health Notions (2018). He conducts research in the areas of community development, educational technology, teaching pedagogies, educational management, and arts and humanities. 